\title{
FAKTOR-FAKTOR YANG BERHUBUNGAN DENGAN SISA MAKANAN PADA PASIEN KANKER PAYUDARA DI RUMAH SAKIT DADI KELUARGA PURWOKERTO
}

\section{RELATED FACTORS WITH REST OF FOOD IN BREAST CANCER PATIENTS IN DADI KELUARGA HOSPITAL PURWOKERTO}

\author{
Triana Uji Pamungkas, Dyah Nur Subandriani
}

\begin{abstract}
Background : Visually observed in July - September 2016 the remaining food by $33 \%$. While the results of visual observation of food residuals in breast cancer patients in January 2017 that is equal to $29.6 \%$. This is not in accordance with the SPM is $<20 \%$.

Objective : To know the factors associated with the food of breast cancer patients at Dadi Keluarga Hospital Purwokerto.
\end{abstract}

Methods : The cross sectional study design was 38 samples. The data were obtained using questionnaires: appetite, psychic condition, food from outside hospital, family support, food appearance, food taste, and food residual form. The test used was chi square with $\alpha=0,05$.

Results : The rest of the food was not eaten by patients $57.9 \%$. Factors that influence the rest of the food include appetite 55,3\%, normal psychic condition 60,5\%, food from outside hospital 52,6\%, family support 55,3\%, appearance $55,3 \%$ and food taste $55,3 \% \%$. There was no association of feeding of breast cancer patients with appetite $(p=0,154)$, and psychic condition $(p=0,646)$. There was association of leftover food in breast cancer patients with food from outside hospital $(p=0,019)$, family support $(p=0,006)$, food appearance $(p=0,006)$, and food taste $(p=0,011)$.

Conclusion : The most associated factor with the remaining food of breast cancer patients is family support.

Keywords : food waste, breast cancer

\section{ABSTRAK}

Latar Belakang : Hasil observasi secara visual di Rumah Sakit Dadi Keluarga Purwokerto sisa makanan pada pasien kanker payudara pada bulan Januari 2017 yaitu sebesar 29,6 \%. Hal ini tidak sesuai dengan Standar Pelayanan Minimal (SPM) yaitu $<20 \%$.

Tujuan Penelitian : untuk mengetahui faktor-faktor yang berhubungan dengan sisa makanan pasien kanker payudara di Rumah Sakit Dadi Keluarga Purwokerto.

Metode Penelitian: Rancangan penelitian cross sectional dengan 38 sampel. Data diperoleh menggunakan kuesioner yaitu selera makan, keadaan psikis, makanan dari luar rumah sakit, dukungan keluarga, penampilan makan, rasa makanan dan formulir taksiran sisa makanan. Uji yang digunakan adalah chi square dengan $\alpha=0,05$.

Hasil: Sisa makanan yang tidak dimakan pasien $57,9 \%$. Faktor yang mempengaruhi sisa makanan diantaranya selera makan 55,3\%, keadaan psikis normal 60,5\%, makanan dari luar rumah sakit 52,6\%, dukungan keluarga $55,3 \%$, penampilan makan 55,3\% dan rasa makanan 55,3\%. Tidak ada hubungan sisa makanan pasien kanker payudara dengan selera makan $(p=0,154)$, dan keadaan psikis $(p=0,646)$. Ada hubungan sisa makanan pada pasien kanker payudara dengan makanan dari luar rumah sakit $(p=0,019)$, dukungan keluarga $(p=0,006)$, penampilan makanan $(p=0,006)$, dan rasa makanan $(p=0,011)$.

Kesimpulan: Faktor yang paling berhubungan dengan sisa makanan pasien kanker payudara yaitu dukungan keluarga. 


\section{PENDAHULUAN}

Kanker payudara merupakan keganasan yang paling sering terjadi pada wanita dan penyebab kematian tertinggi pada wanita umur 4044 tahun ${ }^{3}$. Kanker payudara pada tahun 2008 mencapai 39.831 atau $25,5 \%$ dari seluruh keganasan yang terjadi pada wanita ${ }^{16}$. Sedangkan di Indonesia, angka kejadian kanker payudara diperkirakaan sebesar 26 kejadian setiap 100.000 wanita (Depkes RI, 2010; Sjafii.,et al.,2008).

Manusia mempunyai sifat yang holistik yaitu makhluk fisik dan sekaligus psikologis, yang saling mempengaruhi (Lubis,2009). Hal ini dapat kita lihat pada penderita penyakit kronis seperti kanker payudara. Reaksi psikologis yang dapat muncul setelah pasien divonis kanker payudara pada umumnya merasa shock mental, takut, tidak bisa menerima kenyataan, sampai pada keadaan depresi yang mengakibatkan nafsu makan pasien turun serta hilangnya selera makan, sehingga akan mengakibatkan adanya sisa makanan.

Menurut standar pelayanan minimal (SPM) yang dianjurkan oleh Departemen Kesehatan RI (2008), sisa makanan harus kurang atau tidak boleh sama dengan 20\%. Oleh karena itu, pencatatan sisa makanan sangat diperlukan untuk mengetahui sisa makanan pasien dan untuk mengevaluasi keberhasilan suatu pelayanan gizi rumah sakit terutama dalam hal penyelenggaraan makanan. Faktor-faktor yang mempengaruhi terjadinya sisa makanan pada pasien kanker meliputi faktor internal dan faktor eksternal.

Rumah sakit Dadi Keluarga merupakan rumah sakit umum yang bertipe $\mathrm{C}$ yang ada di Purwokerto. Sebagian besar (80\%) pasien yang ada di Rumah sakit Dadi Keluarga Purwokerto ini adalah pasien kanker. Hasil observasi secara visual yang pernah dilakukan di instalasi gizi Rumah Sakit Dadi Keluarga Purwokerto, menunjukkan masih adanya sisa makanan. Pada bulan Juli - September 2016 sisa makanan sebesar 33\%. Sedangkan hasil observasi secara visual sisa makanan pada pasien kanker payudara pada bulan Januari 2017 yaitu sebesar $29,6 \%$. Hal ini tidak sesuai dengan SPM yaitu $<20 \%$.

Kesehatan merupakan salah satu upaya pembangunan nasional yang diarahkan guna mencapai kesadaran, kemauan dan kemampuan untuk hidup sehat ${ }^{11}$. Salah satu permasalahan di bidang kesehatan dan merupakan ancaman di seluruh negara terutama di negara berkembang adalah peningkatan prevalensi penyakit kanker.

Rumah sakit Dadi Keluarga merupakan rumah sakit umum yang bertipe $\mathrm{C}$ yang ada di Purwokerto. Sebagian besar (80\%) pasien yang ada di Rumah sakit Dadi Keluarga Purwokerto ini adalah pasien kanker. Hasil observasi secara visual yang pernah dilakukan di instalasi gizi Rumah Sakit Dadi Keluarga Purwokerto, menunjukkan masih adanya sisa makanan. Pada bulan Juli - September 2016 sisa makanan sebesar 33\%. Sedangkan hasil observasi secara visual sisa makanan pada pasien kanker payudara pada bulan Januari 2017 yaitu sebesar $29,6 \%$. Hal ini tidak sesuai dengan SPM yaitu $<20 \%$. Berdasarkan latar belakang tersebut, maka peneliti tertarik untuk meneliti faktor-faktor yang berhubungan dengan sisa makanan pada pasien kanker payudara di Rumah Sakit Dadi Keluarga Purwokerto.

\section{METODE}

Penelitian ini dilaksanakan pada bulan Juni 2017. Jenis penelitian yang digunakan dalam penelitian ini adalah penelitian deskriptif analitik, dan rancangan penelitian yang digunakan adalah cross sectional.

Populasi dalam penelitian ini adalah seluruh pasien kanker payudara yang sedang dirawat di RS Dadi Keluarga Purwokerto dan mendapatkan pelayanan makanan dari rumah sakit.Subyek penelitian yang digunakan dalam penelitian ini adalah pasien rawat inap dengan jenis penyakit kanker payudara di RS Dadi Keluarga Purwokerto Jumlah populasinya sebanyak 38 orang.

Cara Pengumpulan Data diperoleh langsung dari responden melalui pengukuran observasi dan wawancara. Wawancara menggunakan kuesioner meliputi identitas responden, selera makan, keadaan psikis, dukungan keluarga, makanan dari luar rumah sakit, penampilan dan rasa makanan sedangkan observasi dengan menggunakan formulircomstok untuk mengetahui sisa makanan pasien.

Analisi data dilakukan dengan cara univariat, bivariat dan multivariat. Analisis univariat bertujuan untuk mendeskripsikan masing-masing variabel yaitu variabel selera makan, variabel keadaan psikis, variable makanan dari luar rumah sakit, variabel dukungan keluarga, variable penampilan makan dan variable rasa makanan. Analisis bivariat digunakan untuk mengetahui hubungan antara variabel selera makan dengan sisa makanan, keadaan psikis dengan sisa makanan, makanan dari luar rumah sakit dengan sisa makanan, dukungan keluarga dengan sisa makanan, penampilan makanan dengan sisa makanan dan rasa makanan dengan sisa makanan dengan menggunakan uji hubungan chi square 
dengan derajat kepercayaan 95\%. Analisis multivariate yang digunakan dalam penelitian ini adalah regresi linier berganda.

\section{HASIL DAN PEMBAHASAN}

A. Hasil Penelitian

Penelitian tentang "Faktor-Faktor Yang Berhubungan Dengan Sisa Makanan Pasien Kanker Payudara di Rumah Sakit Dadi Keluarga Purwokerto" yang dilakukan pada bulan Mei-Juni 2017 didapatkan hasil penelitian diuraikan seperti dibawah ini:

\section{Analisa Univariat}

a. Gambaran selera makan pada pasien kanker payudara

Tabel 4.2 Distribusi Frekuensi selera makan terhadap sisa makanan pada pasien kanker payudara di RS Dadi Keluarga Purwokerto Tahun 2017

\begin{tabular}{lcc}
\hline Selera makan & $\mathrm{N}$ & $\%$ \\
\hline Selera & 21 & 55,3 \\
Tidak Selera & 17 & 44,7 \\
\hline Total & 38 & 100,0 \\
\hline
\end{tabular}

Berdasarkan tabel 4.2 dapat diketahui bahwa sebagian besar selera makan respondenyang berselera sebanyak 21 responden (55,3\%). Selera makan adalah keinginan seseorang untuk makan dan ketertarikan pada suatu makanan karena suatu respon terhadap rangsangan ${ }^{42}$. Selera makan biasanya dipengaruhi oleh keadaan dan kondisi seseorang. Pada umumnya, nafsu makan akan menurun pada orang sakit atau dalam keadaan susah. Begitu pula sebaliknya, nafsu makan akan baik atau bahkan meningkat pada orang sehat atau dalam keadaan senang.

b. Gambaran keadaan psikis pada pasien kanker payudara

Tabel 4.3 Distribusi Frekuensi keadaan psikis terhadap sisa makanan pada pasienkanker payudara di RS Dadi Keluarga Purwokerto Tahun 2017

\begin{tabular}{lcc}
\hline Keadaan psikis & $\mathrm{N}$ & $\%$ \\
\hline Abnormal & 15 & 39,5 \\
Normal & 23 & 60,5 \\
\hline Total & 38 & 100,0 \\
\hline
\end{tabular}

Pasien yang menjalani pengobatan di rumah sakit dapat menunjukkan beragam masalah atau persoalan yang berkaitan dengan kondisi psikologis mereka. Hal yang paling umum dialami oleh pasien adalah kecemasan dan depresi. Berdasarkan tabel 4.3 dapat diketahui bahwa sebagian besar keadaan psikis responden adalah normal/ baik sebanyak 23 responden $(60,5 \%)$.

c. Gambaran makanan dari luar rumah sakit pada pasien kanker payudara

Tabel 4.4 Distribusi Frekuensi makanan dari luar rumah sakit terhadap sisa makanan pada pasien kanker payudara di RS Dadi Keluarga Purwokerto Tahun 2017

\begin{tabular}{lcc}
\hline Makanan dari luar RS & N & $\%$ \\
\hline Ya & 18 & 47,4 \\
Tidak & 20 & 52,6 \\
\hline Total & 38 & 100,0 \\
\hline
\end{tabular}

Berdasarkan tabel 4.4 dapat diketahui bahwa sebagian besar responden tidak membawa makan dari luar sebanyak 20 responden (52,6\%). Makanan yang dimakan oleh pasien yang berasal dari luar rumah sakit berpengaruh terhadap terjadinya sisa makanan ${ }^{2}$. Pasien yang mendapatkan makanan dari luar rumah sakit menyisakan lebih banyak makanan dari pada pasien yang tidak mendapatkan makanan dari luar rumah sakit ${ }^{24}$.

d. Gambaran Dukungan keluarga pada pasien kanker payudara

Tabel 4.5 Distribusi Frekuensi dukungan keluarga terhadap sisamakanan pada pasien kanker payudara di RS Dadi Keluarga Purwokerto Tahun 2017

\begin{tabular}{lcc}
\hline Dukungan Keluarga & $\mathrm{N}$ & $\%$ \\
\hline Tidak & 17 & 44,7 \\
Mendukung & 21 & 55,3 \\
\hline Total & 38 & 100,0 \\
\hline
\end{tabular}


Adanya dukungan keluarga yang tinggiakan membuat pasien merasanyaman dan mengurangi tekananpsikologis yang dialami pasien seperti rasa takut karena sakit yangdapat menyebabkan hilangnya nafsumakan pasien, sehingga diperlukanmotivasi yang tinggi untukmenghabiskan makanan yangdisajikan rumah sakit karena bergunauntuk kesembuhan pasien danmengurangi terjadinya sisa makana. Berdasarkan tabel 4.5 dapat diketahui bahwa sebagian besar responden mendapat dukungan keluarga sebanyak 21 responden (55,3\%).

e. Gambaran penampilan makanana pada pasien kanker payudara

Tabel 4.6 Distribusi Frekuensi penampilan makanan terhadap sisa makanan pada pasien kanker payudara di RS Dadi Keluarga Purwokerto Tahun 2017

\begin{tabular}{lcc}
\hline Penampilan makanan & $\mathrm{N}$ & $\%$ \\
\hline Baik & 21 & 55,3 \\
Kurang & 17 & 44,7 \\
\hline Total & 38 & 100,0 \\
\hline
\end{tabular}

Berdasarkan tabel 4.6 dapat diketahi bahwa sebagian besar penampilan makanan rumah sakit menurut responden adalah baik sebanyak 21 responden (55,3\%). Penampilan makanan meliputi warna, bentuk, porsi dan penyajian makanan. Penyajian makanan merupakan faktor penentu di dalam penampilan makanan yang disajikan.

f. Gambaran rasa makanan pada pasien kanker payudara

Tabel 4.7 Distribusi Frekuensi rasa makanan terhadap sisa makanan pada pasien kanker payudara di RS Dadi Keluarga Purwokerto Tahun 2017

\begin{tabular}{lcc}
\hline Rasa Makanan & $\mathrm{N}$ & $\%$ \\
\hline Baik & 21 & 55,3 \\
Kurang & 17 & 44,7 \\
\hline Total & 38 & 100,0 \\
\hline
\end{tabular}

Rasa makanan merupakan faktor yang menentukan cita rasa makanan. Rasa makanan akan merangsang indera penciuman dan indera pengecap. Komponen yang berperan dalam menentukan cita rasa makanan tersebut adalah aroma, bumbu, konsistensi makanan, keempukan makanan dan temperature makanan. Pada tabel 4.2 dapat diketahui bahwa sebagian besar rasa makanan menurut responden adalah baik sebanyak 21 responden $(55,3 \%)$.

g. Gambaran sisa makanan pada pasien kanker payudara di Rumah Sakit Dadi Keluarga Purwokerto

Sisa makanan merupakan banyaknya jumlah makanan yang tidak dimakan oleh pasien dari yang disajikan oleh rumah sakit menurut jenis makanannya. Indikator keberhasilan suatu penyelenggaraan makanan rumah sakit dapat dilihat dari sisa makanan dari setiap jenis hidangan. Menurut standar pelayanan minimal (SPM) yang dianjurkan oleh Pedoman Gizi Rumah Sakit (PGRS,2013), sisa makanan harus kurang atau tidak boleh sama dengan $20 \%$.

Tabel 4.8 Distribusi Frekuensi Sisa Makanan Pada Pasien Kanker Payudara di Rumah Sakit Dadi Keluarga Purwokerto

\begin{tabular}{ccc}
\hline Sisa Makanan & $\mathbf{n}$ & $\mathbf{( \% )}$ \\
\hline Banyak & 22 & 57,9 \\
Sedikit & 16 & 42,1 \\
\hline Total & 38 & 100 \\
\hline
\end{tabular}

Tabel 4.3 menunjukan bahwa sebagian besar sisa makanan responden adalah banyak yaitu 22 responden $(57,9 \%)$ dan sebagian kecil sisa makanan responden adalah sedikit yaitu 16 responden $(42,1 \%)$.

\section{Analisa Bivariat}

a. Hubungan selera makan dengan sisa makanan pada pasien kanker payudara di Rumah Sakit Dadi Keluarga Purwokerto

Tabel 4.9 Hubungan Selera Makan Dengan Sisa Makanan Pada Pasien Kanker Payudara di Rumah Sakit Dadi Keluarga Purwokerto

\begin{tabular}{cccccccc}
\hline \multirow{2}{*}{$\begin{array}{c}\text { Selera } \\
\text { Makan }\end{array}$} & \multicolumn{3}{c}{ Sisa Makanan } & \multicolumn{2}{c}{ Total } & \\
\cline { 2 - 5 } & \multicolumn{2}{c}{ Banyak } & \multicolumn{2}{c}{ Sedikit } & & & \\
\cline { 2 - 6 } & $\mathrm{n}$ & $\%$ & $\mathrm{n}$ & $\%$ & $\mathrm{n}$ & $\%$ & \\
\hline Selera & 10 & 47,6 & 11 & 52,4 & 21 & 100 & \multirow{2}{*}{0,154} \\
Tidak & 12 & 70,6 & 5 & 29,4 & 17 & 100 & \\
\hline Total & 22 & & 16 & & 38 & 100 & POR: 0,379 \\
\hline
\end{tabular}

Berdasarkan tabel 4.9 dapat diketahui bahwa responden dengan selera makan terhadap 
makanan Rumah Sakit dalam kategori selera sebagian besar memiliki sisa makanan yang sedikit sebanyak 11 responden (52,4\%) dan responden dengan selera makan terhadap makanan Rumah Sakit dalam kategori tidak selera sebagian besar memiliki sisa makanan yang banyak sebanyak 12 responden (70,6\%). Hasil uji chi-square didapatkan nilai $\rho$-value sebesar 0,154 dan nilai POR sebesar 0,379. Hal ini menunjukan bahwa nilai $\rho$-value $>$ taraf signifikansi $(\alpha)$ yaitu $0,154>0,05$ dan $P O R<1$. Sehingga dapat diartikan bahwa tidak ada hubungan antara selera makan dengan sisa makanan pada pasien kanker payudara dan selera makanan bukan merupakan faktor risiko sisa makanan.

Masih adanya sisa makanan yang disajikan oleh rumah sakit dikarenakan ketidak mampuan pasien dalam menghabiskan porsi makanan yang disajikan, hal ini dikarenakan kondisi pasien yang sedang sakit dan kurangnya motivasi dari keluarga untuk selalu mengingatkan dan mematuhi aturan makanan yang disajikan seperti menghabiskan makanan yang disajikan oleh rumah sakit.

Selain dari hal tersebut mayoritas responden yang di diteliti merupakan pasien yang belum melakukan kemoterapi, sehingga untuk selera makan pasien masih baik dan belum terganggu indra pengecapanya.

b. Hubungan keadaan psikis dengan sisa makanan pada pasien kanker payudara di Rumah Sakit Dadi Keluarga Purwokerto

Tabel 4.10 Hubungan Keadaan Psikis Dengan Sisa Makanan Pada Pasien Kanker Payudara di Rumah Sakit Dadi Keluarga Purwokerto

\begin{tabular}{cccccccc}
\hline \multirow{2}{*}{$\begin{array}{c}\text { Kondisi } \\
\text { Psikis }\end{array}$} & \multicolumn{3}{c}{ Sisa Makanan } & \multicolumn{2}{c}{ Total } & \multirow{2}{*}{ ค-value } \\
\cline { 2 - 5 } & \multicolumn{2}{c}{ Banyak } & \multicolumn{2}{c}{ Sedikit } & & \\
\cline { 2 - 6 } & $\mathrm{n}$ & $\%$ & $\mathrm{n}$ & $\%$ & $\mathrm{n}$ & $\%$ & \\
\hline Abnormal & 8 & 53,3 & 7 & 46,7 & 15 & 100 & \multirow{2}{*}{0,646} \\
Normal & 14 & 60,9 & 9 & 39,1 & 23 & 100 & \\
\hline Total & 22 & & 16 & & 38 & 100 & POR: 0,735 \\
\hline
\end{tabular}

Berdasarkan tabel 4.10 dapat diketahui bahwa responden dengan kondisi psikis abnormal sebagian besar memiliki sisa makanan yang banyak yaitu 8 responden $(53,3 \%)$ dan responden dengan kondisi psikis normal sebagian besar memiliki sisa makanan yang banyak yaitu 14 responden $(60,9 \%)$. Hasil uji chisquare didapatkan nilai $\rho$-value sebesar 0,646 dan nilai POR sebesar 0,735 . Hal ini menunjukan bahwa nilai $\rho$-value $>$ taraf signifikansi $(\alpha)$ yaitu
$0,646>0,05$ dan POR $<1$. Sehingga dapat diartikan bahwa tidak ada hubungan antara kondisi psikis dengan sisa makanan pada pasien kanker payudara dan kondisi psikis bukan merupakan faktor risiko sisa makanan.

c. Hubungan makanan dari luar rumah sakit dengan sisa makanan pada pasien kanker payudara di Rumah Sakit Dadi Keluarga Purwokerto

Tabel 4.11 Hubungan Makanan Dari Luar Rumah Sakit Dengan Sisa Makanan Pada Pasien Kanker Payudara di Rumah Sakit Dadi Keluarga Purwokerto

\begin{tabular}{cccccccc}
\hline Makanan & \multicolumn{4}{c}{ Sisa Makanan } & \multicolumn{2}{c}{ Total } & \\
\cline { 2 - 5 } dari Luar & \multicolumn{2}{c}{ Banyak } & \multicolumn{2}{c}{ Sedikit } & & & \\
\cline { 2 - 6 } RS & $\mathrm{n}$ & $\%$ & $\mathrm{n}$ & $\%$ & $\mathrm{n}$ & $\%$ & \\
\hline Ya & 14 & 77,8 & 4 & 22,2 & 18 & 100 & \multirow{2}{*}{0,019} \\
Tidak & 8 & 40 & 12 & 60 & 20 & 100 & \\
\hline Total & 22 & & 16 & & 38 & 100 & POR: 0,190 \\
\hline
\end{tabular}

Berdasarkan tabel 4.11 dapat diketahui bahwa responden yang membawa makanan dari luar RS sebagian besar memiliki sisa makanan yang banyak yaitu 14 responden (77,8\%) dan responden yang tidak membawa makanan dari luar RS sebagian besar memiliki sisa makanan yang sedikit yaitu 12 responden (60\%). Hasil uji chi-square didapatkan nilai $\rho$-value sebesar 0,019 dan nilai POR sebesar 0,190. Hal ini menunjukan bahwa nilai $\rho$-value $\leq$ taraf signifikansi $(\alpha)$ yaitu $0,019 \leq 0,05$ dan $P O R<1$. Sehingga dapat diartikan bahwa ada hubungan antara membawa makanan dari luar RS dengan sisa makanan pada pasien kanker payudara dan membawa makanan dari luar RS bukan merupakan faktor risiko sisa makanan.

Hal ini sesuai dengan teori yang diungkapkan oleh Moehji (1992) bahwa makanan yang dimakan oleh pasien yang berasal dari luar RS akan berpengaruh terhadap terjadinya sisa makanan.

Berdasarkan hasil penelitian yang dilakukan, jenis makanan dari luar rumah sakit yang dominan dikonsumsi oleh responden adalah jenis snack dan buah dan salah satu alasan responden mengkonsumsi makanan dari luar rumah sakit karena jenis snack yang di konsumsi lebih praktis, lebih enak/ sesuai selera. Adanya makanan dari luar rumah sakit yang dimakan oleh pasien disebabkan oleh budaya membawa oleh-oleh ketika membesuk pasien. 
d. Hubungan dukungan keluarga dengan sisa makanan pada pasien kanker payudara di Rumah Sakit Dadi Keluarga Purwokerto

Tabel 4.12 Hubungan Dukungan Keluarga Dengan Sisa Makanan Pada Pasien Kanker Payudara di Rumah Sakit Dadi Keluarga Purwokerto

\begin{tabular}{|c|c|c|c|c|c|c|c|}
\hline \multirow{3}{*}{$\begin{array}{l}\text { Dukungan } \\
\text { Keluarga }\end{array}$} & \multicolumn{4}{|c|}{ Sisa Makanan } & \multirow{2}{*}{\multicolumn{2}{|c|}{ Total }} & \multirow{3}{*}{$\rho$-value } \\
\hline & \multicolumn{2}{|c|}{ Banyak } & \multicolumn{2}{|c|}{ Sedikit } & & & \\
\hline & $\mathrm{n}$ & $\%$ & $\mathrm{~N}$ & $\%$ & $\mathrm{~N}$ & $\%$ & \\
\hline Mendukung & 8 & 38,1 & 13 & 61,9 & 21 & 100 & \multirow{2}{*}{0,006} \\
\hline Tidak & 14 & 82,4 & 3 & 17,6 & 17 & 100 & \\
\hline Total & 22 & & 16 & & 38 & 100 & POR: 0,132 \\
\hline
\end{tabular}

Berdasarkan tabel 4.12 dapat diketahui bahwa responden dengan dukungan keluarga mendukung sebagian besar memiliki sisa makanan yang sedikit sebanyak 13 responden $(61,9 \%)$ dan responden dengan dukungan keluarga tidak mendukung sebagian besar memiliki sisa makanan yang banyak sebanyak 14 responden (82,4\%). Hasil uji chi-square didapatkan nilai $\rho$-value sebesar 0,006 dan nilai POR sebesar 0,132. Hal ini menunjukan bahwa nilai $\rho$-value $\leq$ taraf signifikansi $(\alpha)$ yaitu $0,006 \leq$ 0,05 dan $P O R<1$. Sehingga dapat diartikan bahwa ada hubungan antara dukungan keluarga dengan sisa makanan pada pasien kanker payudara dan dukungan keluarga bukan merupakan faktor risiko sisa makanan.

Pasien yang memiliki dukungan keluarga yang baik akan mempunyai perasaan yang nyaman yang dapat meningkatkan motivasi mereka untuk patuh terhadap anjuran diet yang telah ditentukan oleh ahli gizi sehingga pasien dapat menurunkan sisa makanan. Peran keluarga sangat penting untuk mendorong pasien agar mau menghabiskan makanannya dengan cara menyuapi sedikit demi sedikit, dengan begitu makanan tidak akan banyak yang tersisa.

e. Hubungan penampilan makanan dengan sisa makanan pada pasien kanker payudara di Rumah Sakit Dadi Keluarga Purwokerto

Tabel 4.13 Hubungan Penampilan Makanan Dengan Sisa Makanan Pada Pasien Kanker Payudara di Rumah Sakit Dadi Keluarga Purwokerto

\begin{tabular}{cccccccc}
\hline \multirow{2}{*}{$\begin{array}{c}\text { Penampilan } \\
\text { Makanan }\end{array}$} & \multicolumn{3}{c}{ Sisa Makanan } & \multicolumn{2}{c}{ Total } & \\
\cline { 2 - 5 } & \multicolumn{2}{c}{ Banyak } & \multicolumn{2}{c}{ Sedikit } & & & \\
\cline { 2 - 6 } & $\mathrm{N}$ & $\%$ & $\mathrm{n}$ & $\%$ & $\mathrm{n}$ & $\%$ & \\
\hline Baik & 8 & 38,1 & 13 & 61,9 & 21 & 100 & \multirow{2}{*}{0,006} \\
Tidak & 14 & 82,4 & 3 & 17,6 & 17 & 100 & \\
\hline Total & 22 & & 16 & & 38 & 100 & POR: 0,132 \\
\hline
\end{tabular}

Berdasarkan tabel 4.13 dapat diketahui bahwa responden yang mengatakan penampilan makanan baik sebagian besar memiliki sisa makanan yang sedikit sebanyak 13 responden $(61,9 \%)$ dan responden yang mengatakan penampilan makanan kurang sebagian besar memiliki sisa makanan yang banyak sebanyak 14 responden (82,4\%). Hasil uji chi-square didapatkan nilai $\rho$-value sebesar 0,006 dan nilai POR sebesar 0,132. Hal ini menunjukan bahwa nilai $\rho$-value $\leq$ taraf signifikansi $(\alpha)$ yaitu $0,006 \leq$ 0,05 dan $P O R<1$. Sehingga dapat diartikan bahwa ada hubungan antara penampilan makanan dengan sisa makanan pada pasien kanker payudara dan penampilan makanan bukan merupakan faktor risiko sisa makanan. Penyajian makanan merupakan faktor terakhir dari proses penyelenggaraan menu makanan. Meskipun makanan diolah dengan cita rasa yang tinggi tetapi bila dalam penyajiaannya tidak dilakukan dengan baik, maka nilai makanan tersebut tidak akan berarti, karena makanan yang ditampilkan waktu disajikan akan merangsang indera penglihatan sehingga menimbulkan selera yang berkaitan dengan cita rasa (Moehyi, 1992).

Aspek penampilan makanan terdiri dari warna makanan, bentuk makanan, porsi dan cara penyajian makanan.

Berdasarkan hasil penelitian, responden menyatakan kurang suka dengan warna makanan sehingga menimbulkan sisa makanan. Pada penelitian ini menggunakan menu ke 10. Responden menyatakan warna tidak sesuai yaitu pada menu makanan pagi yaitu terdiri dari lauk hewani bistik rolade ayam, lauk nabati tahu goreng dan sayur kuah caisim, dari ketiga jenis makanan tersebut responden menyatakan warna makanan tidak sesuai pada hidangan sayur yaitu kuah caisim, karena pada hidangan tersebut terdapat responden yang menyatan bahwa caisim berwarna hijau tua/ over cook. Dan untuk hidangan bistik ayam dan rolade ayam responden mengatakan warna makanan dominan berwarna coklat.

Menurut hasil penelitian, sebagian besar responden mengatakan bentuk makanan yang menarik. Hal ini dikarenakan dalam penyajian makanan untuk lauk hewani sudah berbeda- 
beda di setiap waktu makan misalnya makan pagi lauk hewani dalam bentuk rolade/ menggunakan ayam cincang bukan ayam utuh, makan siang telur ceplok asam manis dan makan malam pepes patin, dari ketiganya bentuk makanan sudah jelas berbeda dan lebih bervariasi. Sedangkan untuk lauk nabati responden juga mengatakan bahwa bentuk makanan sudah baik karena untuk penggunaan tahu dan tempe sudah diolah dan disajikan setiap waktu makan dengan berbeda bentuk. Menurut hasil penelitian, responden sebagian besar mengatakan porsinya sudah sesuai. Di RS Dadi Keluarga Purwokerto, porsi makan pasien tanpa diit sama tidak ada perbedaan antara laki dan perempuan namun hanya dibedakan pada jenis diit tertentu saja yang jumlah porsinya berbeda. Di Instalasi gizi RS Dadi keluarga juga sudah dilengkapi dengan standar porsi serta standar diit pasien.

Berdasarkan hasil penelitian, responden mengatakan bahwa penyajian makanan yang diberikan disukai namun terdapat responden yang masih meninggalkan sisa makanannya. Hal ini tidak sesuai dengan Tanaka (1998) yang menyatakan bahwa tiga hal pokok yang harus diperhatikan dalam penyajian, yaitu pemilihan alat makan yang digunakan, cara menyusun makanan ke dalam tempat sajian atau wadah makan, dan cara menghias hidangan.

Dalam penyajian makanan, memang ada perbedaan antara responden yang dirawat di ruang perawatan kelas VIP, kelas 1 , kelas 2, dan kelas 3.

f. Hubungan rasa makanan dengan sisa makanan pada pasien kanker payudara di Rumah Sakit Dadi Keluarga Purwokerto

Tabel 4.14 Hubungan Rasa Makanan Dengan Sisa Makanan Pada Pasien Kanker Payudara di Rumah Sakit Dadi Keluarga Purwokerto

\begin{tabular}{cccccccc}
\hline \multirow{2}{*}{ Rasa } & \multicolumn{4}{c}{ Sisa Makanan } & \multirow{2}{*}{ Total } & \multirow{2}{*}{$\rho$-value } \\
\cline { 2 - 6 } Makanan & \multicolumn{2}{c}{ Banyak } & \multicolumn{2}{c}{ Sedikit } & & & \\
\cline { 2 - 6 } & $\mathrm{N}$ & $\%$ & $\mathrm{n}$ & $\%$ & $\mathrm{n}$ & $\%$ & \\
\hline Baik & 6 & 35,3 & 11 & 64,7 & 17 & 100 & \multirow{2}{*}{0,011} \\
Kurang & 16 & 76,2 & 5 & 23,8 & 20 & 100 & \\
\hline Total & 22 & & 16 & & 38 & 100 & POR: $0,17 \mathrm{C}$ \\
\hline
\end{tabular}

Berdasarkan tabel 4.14 dapat diketahui bahwa responden yang mengatakan rasa makanan baik sebagian besar memiliki sisa makanan yang sedikit sebanyak 11 responden $(64,7 \%)$ dan responden yang mengatakan rasa makanan kurang sebagian besar memiliki sisa makanan yang banyak sebanyak 16 responden (76,2\%). Hasil uji chi-square didapatkan nilai $\rho$ value sebesar 0,011 dan nilai POR sebesar 0,170 . Hal ini menunjukan bahwa nilai $\rho$-value $\leq$ taraf signifikansi $(\alpha)$ yaitu $0,011 \leq 0,05$ dan POR < 1. Sehingga dapat diartikan bahwa ada hubungan antara rasa makanan dengan sisa makanan pada pasien kanker payudara dan rasa makanan bukan merupakan faktor risiko sisa makanan.

Selain penampilan makanan, faktor utama yang menentukan citarasa adalah rasa makanan. Rasa makanan meliputi aroma, bumbu, konsistensi, keempukan, dan temperature.

\section{a) Aroma makanan}

Dalam penelitian Mutyana (2011) yang menyatakan bahwa adanya hubungan bermakna antara aroma makanan dengan sisa makanan pasien rawat inap di rumah sakit. Aroma yang dikeluarkan oleh setiap makanan berbeda-beda.

\section{b) Bumbu}

Berdasarkan hasil penelitian, beberapa responden juga mengatakan bumbu pada makanan tidak terasa, hal ini dikarenakan kebiasaan responden yang suka makan asin, manis dan pedas. Selain itu ada beberapa responden yang menjalani kemoterapi sehingga untuk indra perasanyapun terganggu akibat dari kemo terapi tersebut, yaitu lidah tersa pahit, hambar dan saryawan yang menyebabkan bumbu makanan tidak terasa.

\section{c) Konsistensi Makanan}

Menurut hasil penelitian, konsistensi makanan jenis nasi paling banyak menyisakan makanan. Rata-rata dari responden tidak menyukai makanan lunak (bubur), meskipun sakit responden lebih memilih makanan biasa (nasi) karena responden lebih terbiasa dengan makanan biasa daripada makanan lunak sehingga menimbulkan sisa makanan yang banyak pada bubur.

\section{d) Keempukan Makanan}

Menurut hasil penelitian, sebagian besar mengatakan bahwa tingkat keempukan makanan yang di sajikan di setiap kali waktu makan sudah sesuai.Bahan makanan golongan lauk hewani yang di gunakan meliputi ikan patin, ikan guramih, telur dan ayam, bahan makanan tersebut merupakan bahan makanan yang mudah untuk di oalah dengan tekstur yang empuk. 


\section{e) Temperatur}

Berdasarkan hasil penelitian, rata - rata responden menyatakan suhu penyajian makanan tidak sesuai. Hal ini dikarenakan, responden yang tidak segera menyantap makanannya langsung atau masih dalam kondisi hangat. Selain itu troli pengangkut makanan masih belum terdapat pemanas, sehingga makanan yang sampai pada pasien hanya dalam kondisi hangat bahkan kadang-kadang dingin.

\section{Analisa Multivariat}

Faktor yang paling berhubungandengan sisa makanan pasien kanker payudara di Rumah Sakit Dadi Keluarga Purwokerto

Tabel 4.15 Distribusi Frekuensi Faktor Yang Paling BerhubunganDengan Sisa Makanan Pasien Kanker Payudara di Rumah Sakit Dadi Keluarga Purwokerto

\begin{tabular}{cccc}
\hline Variabel & Exp (B) & Lower & Upper \\
\hline Makanan Dari Luar & 5,106 & 0,867 & 30,066 \\
RS & 5,595 & 0,832 & 37,617 \\
Dukungan Keluarga & 3,133 & 0,471 & 20,845 \\
Penampilan Makanan & 4,381 & 0,780 & 24,594 \\
Rasa Makanan & 0,026 & & \\
Constant & & & \\
\hline
\end{tabular}

Berdasarkan tabel 4.15 dapat diketahui bahwa faktor yang paling berhubungan dengan sisa makanan adalah faktor dukungan keluarga dengan nilai exp (B) adalah 5,595 dan faktor yang paling rendah adalah penampilan makanan dengan nilai exp (B) adalah 3,133.

\section{KESIMPULAN DAN SARAN}

\section{KESIMPULAN}

Ada hubungan makanan dari luar rumah sakit, dukungan keluarga, penampilan makanan, rasa makanan dengan sisa makanan pada pasien kanker payudara di Rumah Sakit Dadi Keluarga Purwokerto dengan nilai $\rho$-value $<0,05$. Sedangkan selera makan dan keadaan psikis tidak ada hubungannya dengan sisa makanan pada pasien kanker payudara.

\section{SARAN}

Saran yang dapat diberikan bagi instalasi gizi diharapkan tetap meningkatkan mutu dan cita rasamakanan yang disajikan agar tidak ada lagi makanan yang tersisa. Peningkatan ketrampilan dan pengetahuan petugas melalui pelatihan,studi banding agar petugas dan juru masak dapat menghasilkan menuyang sesuai selera pasien.

\section{Daftar Pustaka}

1. American Cancer Society. (2011). Breast Cancer Facts \& Figures 2011-2012. Atlanta: American Cancer Society, Inc.

2. Aula, Lisa Ellizabet. 2011. "Faktor-Faktor yang Berhubungan dengan Terjadinya Sisa Makanan Pada Pasien Rawat Inap Di Rumah Sakit Haji Jakarta". Skripsi. Prodi Kesehatan Masyarakat Fakultas Kedokteran dan IImu Kesehatan Universitas Islam Negeri Syarif Hidayatullah Jakarta.

3. Bland $\mathrm{KI}$, Vezeridis MP, and Copeland EM. 2005. The Breast. In: Schwartz's Prinsiples of Surgery. Eight Edition. Graw Hill Inc, New York.

4. Budiyanto M. AK. 2002. Gizi dan Kesehatan. Penerbit Malang.

5. Caninsti, Riselligia. 2007. Gambaran Kecemasan dan Depresi Pada Penderita GagalGinjal Kronis yang Menjalani Terapi Hemodialisa. Tesis. Fakultas PsikologiUniversitas Indonesia.

6. Carr, Deborah. et. al. 2001. Plate Waste Studies. National Food Service Management

7. Comstock, E. M., Pierre R.G., dan Mackierman Y.D.. 1981. Measuring Individual PlateWaste in School Lunches. Visual Estimation and Children's Rating vs Actual Weighingof Plate Waste.J. Am. Dietetic Assoc Volume 94, pp 290-297.

8. Corwin, J.E. 2001. Buku Saku Patofisiologi. Penerbit Buku Kedokteran. Jakarta: EGC.

9. Djamaluddin, M., (2002). Analisis Zat Gizi dan Biaya Sisa Makanan pada Pasien dengan Makanan Biasa di RS. Dr. Sardjito Yogyakarta, Tesis ProgramPascasarjana UGM, Yogyakarta.

10. Depkes RI. 1991. Petunjuk Teknis Penyelenggaraan Rekam Medis / Medical Record Rumah Sakit. Jakarta : DEPKES RI.

11. 2003. Pedoman Pelayanan Gizi Rumah Sakit. Jakarta : Departemen Kesehatan $\mathrm{RI}$

12. 2005. Pedoman Pelayanan Gizi Rumah Sakit. Jakarta : Departemen Kesehatan RI .

13. 2009. Sistem Kesehatan Nasional. Jakarta

$14 . \quad$ 2013. Pedoman Gizi Rumah Sakit. Jakarta : Departemen Kesehatan RI.

15. Friedman, M. 2010. Buku Ajar Keperawatan Keluarga: Riset, teori, dan praktik Ed 5. Jakarta: EGC

16. Globocan, International Agency for Research on Cancer (IARC), 2008. http;//www.Globocan.go.id 
17. Grant, A. E. \& Meadows, J. H. (2008). Communication Technology Update and Fundamental. (ed. 06). Boston: Focal Press

18. Hartono, A , (2000), Asuhan Nutrisi Rumah Sakit, Penerbit Buku Kedokteran, Yogjakarta.

19. Juju Juariah. 2007. Faktor-Faktor yangMempengaruhi Sisa Makanan Biasapada Pasien Kelas III Rawat Inap diRumah Sakit Umum Daerah dr.SoedarsonoPontianak.Skripsi.Program S 1 Gizi Kesehatan UGM,Yogyakarta

20. Kemenkes RI. 2013. Pedoman Pelayanan Gizi Rumah Sakit. Jakarta : Kementerian Kesehatan RI.

21. Khairunnas, 2001. FaktorFaktoryangMempengaruhiTerjadinya Sisa Makananpada Pasien yang dirawatlnap di Rumah Sakit dr.Achmad Mochtar BukitTinggi.Tesis, ProgramPascasarjanaUGM,Yogyakarta

22. Khomsan, Ali. 2004. Pangan dan Gizi untuk Kesehatan. Jakarta: PT Rajagrafindo Persada

23. Kosen, S. 1997. Bunga Rampai Pengembangan Jaminan Pemeliharaan Kesehatan Masyarakat di Indonesia. Departemen Kesehatan RI, Jakarta.

24. Kumboyono dan Rahmi, Y. 2012. Faktor-faktor yang Berhubungan denganPenerimaan Makanan Biasa oleh Pasien di Ruang Rawat Inap Kelas IIIRumah Sakit Tentara dr. Soepraoen Malang. Majalah Kesehatan FKUBJanuari 2012: 1-11

25. Moehyi, Sjahmien. 1992. Penyelenggaraan Makanan Institusi dan Jasa Boga. Jakarta : Penerbit Bhratara.

26. 1995. Pengaturan Makanan dan Diit Untuk Penyembuhan Penyakit. Jakarta: PT. Gramedia Pustaka

27. 1997. Pengaturan Makanan dan Diit Untuk Penyembuhan Penyakit. Jakarta: Gramedia Pustaka Utama.

28. 2008. Standar Pelayanan Minimal Rumah Sakit. Jakarta : Departemen Kesehatan RI.

29. Mutyana, Leni. 2011. Faktor-faktor yang berhubungan dengan daya terima pasienrawat inap di Rumah Sakit Ibu dan Anak Budiasih Serang tahun 2011. Skripsi.Fakultas Kedokteran dan IImu Kesehatan UIN Syarif Hidayatullah Jakarta.

30. Nuryati, Puji. 2008. Hubungan Antara Waktu Penyajian, Penampilan Dan Rasa Makanan Dengan Sisa Makanan Pada Pasien Rawat Inap Dewasa Di Rs Bhakti Wira Tamtama Semarang. Skripsi. Fakultas IImu
Kesehatan Universitas Muhamamadiyah Semarang.

31. Peckenpaugh, Nancy J. 2010. Nutrition Essentials And Diet Therapy. USA : Saunders Elsevier.

32. Priyanto, Oki Hadi. 2009. Faktor yang Berhubungan Dengan Terjadinya Sisa Makanan Pada Pasien Rawat Inap Kelas III di RSUD Kota Semarang.Skrispsi. Fakultas IImu Keolahragaan Universias Negeri Semarang.

33. Raharjo, Toto. 1997. Mutu Penyelenggaraan Makanan Rumah Sakit DI RSU Dr. SoeseloSlawi Dan Rsu Harapan Anda Tegal Ditinjau Dari Sisa Makanan BiasaPasien Rawat Inap. Skripsi. Fakultas Kesehatan Masyarakat UniversitasDiponegoro.

34. Renangtyas, Dewi. et. al. 2004. Pengaruh Penggunaan Modifikasi Standar Resep LaukNabati Tempe terhadap Daya Terima dan Persepsi Pasien Rawat Inap. JurnalGizi Klinik Indonesia. Vol.1. no.1.

35. Suharyati, 2006. "Hubungan Asupan Makan Dengan Status Gizi Pasien DewasaPenyakit Dalam RS Dr. Ciptomangunkusumo Jakarta" (skripsi).Jakarta:Fakultas Kesehatan Masyarakat Universitas Indonesia

36. Supariasa. 2001. Gizi dalam Masyarakat. Jakarta: PT. Elex Media

37. 2002. Penilaian Status Gizi. Jakarta : EGC.

38. Tanaka, Meis Larissa. 1998. Faktor Eksternal Yang Berhubungan dengan Daya TerimaMakan Pasien Rawat Inap Dewasa di Rumah Sakit Umum Tangerang Tahun2008. Tesis. Fakultas Kesehatan Masyarakat Universitas Indonesia.

39. Vina, 2012. Faktor-faktor yangBerhubungandenganPenerimaan

Makanan Biasaoleh Pasien di Ruang RawatInap Kelas III Rumah SakitTentara dr. Soepraoen Malang. TugasAkhir,FakultasKedokteranUniversitas Brawijaya

40. Winarno, F.G. 1992. Kimia Pangan dan Gizi. Jakarta: PT Gramedia Pustaka

41. Utari, R., 2009. Evaluasi Pelayanan Makanan Pasien Rawat Inap di Puskesmas Gondangrejo Karanganyar. Karya Tulis Ilmiah Mahasiswa Program D III GiziFakultas IImu Kesehatan Universitas Muhammadiyah Surakarta. Diunduh: www.google.co.id 19 Desember 2016.

42. Zulfah, S., (2002), Faktor-faktor yang Mempengaruhi terjadinya malnutrisi RS di RSU Dr. Zainoel Abidin Banda Aceh. Tesis, Program Pascasarjana UGM,Yogyakarta 